\title{
Latvijas kultūras un mākslas sovetizācija pirmajā padomju okupācijas gadā: 1940. gada jūnijs - 1941. gada jūnijs. II daḷa
}

\author{
Sovietisation of the Culture and Art of Latvia during the First Year \\ of Occupation: June 1940 - June 1941. Part II
}

\author{
Aivars Stranga, Dr. habil. hist. \\ Latvijas Universitātes Vēstures un filozofijas fakultātes \\ Vēstures un arheoloǵijas nodaḷas profesors, LZA ìstenais loceklis \\ Aspazijas bulvāris 5, Rīga, LV-1050 \\ E-pasts: aivars.stranga@lu.lv
}

Kultūras un mākslas attiecības ar jauno varu - padomju režīmu - ir nopietni pētìtas Latvijas vēstures literatūrā. Ilgoņa Bērsona darbi par literatūras likten,iem, Arnolda Klotina - par mūziku okupācijā un Ilzes Konstantes pētījumi par tēlotāju mākslu ir ievērojami pēdējo gadu sasniegumi. Šajā esejas formas rakstā, papildinot vienu otru faktisko materiālu, veltīta uzmanība kolaborācijai un pat kolaboracionismam. Bez šo parādību plašas izplatības kultūras un mākslas sovetizācijas procesi nebūtu iespējami.

Atslēgvārdi: okupācija, kolaborācija, kolaboracionisms, sociālistiskais reālisms, L̦en,ins, Stalins.

Profound studies are already contained in Latvian history literature about the relations between the culture and art and a new power - Soviet regime. Works of Ilgonis Bērsons dedicated to destiny of literature, Arnolds Klotiņš' description of music under occupation, and research by Ilze Konstante are famous achievements of last years. My article, written as an essay, offers some additional facts, and it is devoted to collaboration and even collaborationism. The extensive prevalence of the aforementioned phenomena enabled the Sovietisation processes of culture and art.

Keywords: occupation, collaboration, collaborationism, socialist realism, Lenin, Stalin.

\section{Dziesma par Stal̨inu}

1940. gada decembrī, Josifa Staļina (Iosif Stalin) dzimšanas dienu atzīmējot, presē tika daudznozīmīgi uzsvērts, ka padomju tautām ir daudzas dziesmas par Stalinu: 
"No tautas vidus nāk slaveni tautas dziesminieki. Visi vini apdzied Staļinu, apspiesto atbrīvotāju, gudro vadoni, bezbailigo kalna èrgli. Kazachu tautas ievērojamais dziesminieks ordennnesis, simts gadu vecais Džambuls radījis daudz dziesmu un poēmu par Staļinu ("Es Staļinu slavēju", "Mūžĭgā uguns", "Dziesma par tautu brālïbu”, "Ar Stalina vārdu gājāt uzvarai pretī", "Asins brā̧liem" un citas; viena no tām skanēja: "Steidzies, mana dziesma, visi kalni lai runā,

Lai sadzird manu balsi visi patrioti.

Dziediet, ziedošās padomju zemes dēli, Uzticìgi Stalıinam būsim lìdz galam!”).”

Latviešiem, par nelaimi, šāda simtgadīga teicēja - analfabēta nebija; apgalvojumi, ka Staḷina tēls esot parādījies latviešu padomju folklorā, radās tikai dažus gadus pēc kara, ${ }^{2}$ un 1940.-1941. gadā uzdevums uzrakstīt dziesmu par Staḷinu gūlās uz profesionālu autoru pleciem. Nopietns pamudinājums bija divu uzbeku dzejnieku dzejojuma "Lielā Ferganas kanāla racēju vēstule Josifam Visarionovičam Staḷinam" tulkojums latviešu valodā, kas tika publicēts 1940. gada beigās. Kanāls, saukts par Lielo Fergānas kanālu, bija tikko uzbūvēts Padomju Savienībā, Uzbekijas un Tadžikijas PSR; tā izbūvē bija piedalījušies vairāk nekā simts tūkstošu uzbeku un tadžiku, un, protams, šĩ grandiozā būve tika raksturota kā tāda, kura bija kḷuvusi iespējama, tikai pateicoties Stalina gēnijam. Minētais sacerējums tika nekavējoties iztulkots krieviski, un no krievu valodas latviski to tagad bija iztulkojis Jānis Sudrabkalns, izraisot Aleksandra Čaka gaviles:

"Lielā Ferganas kanāla racēju dzejiskā "vēstule" ir cēls un aizkustinošs piemērs tam, kādu dziļu, neliekulotu draudzìbu un pateicìbu brīvā uzbeku tauta jūt pret biedru Stalıinu, sava lielā darba iedvesmotāju. Kanāla racēji savu "Vēstuli" ievada un noslēdz ar skaistiem, aforistiski zìmïiem, tautas dzejas gara apdvestiem biedra Stalina cildinājuma distihiem. Ievadā: Tev, lielais vadoni, mēs sūtām sveicienu, No kvēlas dēla sirds un jūtām sveicienu."

Latviešu dzejniekiem bija, no kā mācīties (šis slavinājums laikam bija A. Čaka pirmā nodeva jaunajai varai - sīkāk sk. turpmāk).

Viens no galvenajiem padomju Latvijas uzdevumiem bija gatavošanās Latvijas mākslas dekādei Maskavā (sk. turpmāk). Sakarā ar to Latvijas Komunistiskās (boḷševiku) partijas Centrālās komitejas (CK) Birojs 1941. gada janvārī pieñēma speciālu lēmumu (tas tika uzrakstīts Maskavā), kurā bija ierosināts, cita starpā, radīt poēmu par Stalinu. ${ }^{4}$ Turpinot partijas vadỉbas ideju, 1941. gada martā pazīstami kultūras un mākslas darbinieki aicināja: "Radīsim dziesmu par brivo latviešu tautu un biedru Stalıinu." Šk̉iet, pirmais, kas sacerēja "melodisku dziesmu par Staļinu" - kā tā tika saukta presē, bija vietējais krievu komponists un mūziķis Sergejs Krasnopjorovs (Sergej Krasnoperov), īpaši pazīstams kā balalaiku orķestra vadītājs; dziesma tika atskan,ota koncertā konservatorijā marta beigās. ${ }^{6} \mathrm{Ar}$ to, protams, bija daudz par maz - pie tam tā bija dziesma bez vārdiem. Nopietnāks pieteikums bija dzejolis "Dziesma par Staḷinu", kas aprīlī parādījās žurnālā "Karogs":

\section{Auž māsa zvaigzni karogā \\ Uz sarkana ar zeltu, \\ Un seno dainu valodā \\ Par Stalinu dzied dziesmu tā, \\ Kas dzili sirdì smelta.}

Interesanti, ka tā bija bez paraksta ${ }^{7}$ (anonīma bija arī "Dziesma par traktoru", kura bija veltīta "Stalıina traktoriem": tā bija parādījusies jau janvārī, taču par traktoriem diez vai sāktu dziedāt masu dziesmas). ${ }^{8}$ Nedaudz vēlāk kḷuva zināms, 
ka dziesmas autors ir Fricis Rokpelnis (1909-1969), un mūziku bērnu korim ar nosaukumu "Auž māsa zvaigzni karogā" sacerēja komponiste Paula Līcīte (1889-1966), tas laikam arī pirmajā okupācijas gadā bija viss. ${ }^{9}$ 1941. gada pavasarī bez panākumiem beidzās konkurss par revolucionāru dziesmu; lai arī neviena dziesma netika atzīta par derīgu, tomēr "Vienmēr gatavs" tika uzskatīta par tādu, kurā ir kaut kas pieņemams, un tās autori tika prēmēti ar 500 rubḷiem. Teksta autors bija Valdis Grēviņš (1895-1968), mūzikas autore - P. Līcīte. ${ }^{10} \mathrm{Ar}$ "Dziesmu par Stalinu" ìsti neveicās arī pēc kara. ${ }^{11} 1945$. gada maijā S. Krasnopjorovs sacerēja mūziku dziesmai "Ar tavu vārdu, biedri Staḷin" ar A. Čaka vārdiem, bet padomju Latvijas himnas autors Anatols Liepiņš komponēja kantāti "Līgo Stalinam", ${ }^{12}$ taču nekādu popularitāti tās neieguva un nevarēja tikt salīdzinātas, piemēram, ar Izaka Dunajevska (Izak Dunajevskij) patiešām populārajām masu dziesmām. Atsevišķas dziesmas par Staliınu nav pat J. Sudrabkalna 1947. gada dzejoḷu krājumā "Brāḷu saimē" (kurā, protams, Staḷins ir cildināts vairākkārt - piemēram: "Pār Kremli zvaigzne mirdz, / Kur Staļinam ir mājas, / Kur viña mìlas pilnā sirds / Par tautu kvēlot nenostājas"). ${ }^{13}$ Šis krājums atnesa viņam gan Stalina prēmiju, gan LPSR Tautas dzejnieka nosaukumu, otrajam pēc Raiņa. 1948. gadā publicētajā A. Čaka dzejolu krājumā "Zem cēlās zvaigznes" ieklauts dzejolis "Latvietis biedram Staḷinam", kas bija viens no visuzskatāmākajiem Staḷina kulta piemēriem ("Brauc selgā latvietis un laivā dzied tev dziesmu, / Iet druvā latvietis un tavu vārdu min / Kā lielo palïgu. Viñš savas tautas briesmu / Kā sakni pārkodis un tavu zvaigzni zin”), ${ }^{14}$ taču, šḳiet, pat to nemēgināja likt pamatā kādai masu dziesmai.

1945. un 1949. gadā tika publicēti divi krājumi - "Latviešu dzejnieki Staḷinam" un "Latviešu dzejnieki Stalıinam. Staļina diena" - sakarā ar Staḷina 70 gadu jubileju. Viens no čaklākajiem autoriem bija F. Rokpelnis, kurš publicēja "Dziesmu Stal̦inam”, taču nedz tā kḷuva kaut cik populāra, nedz tika izcelta citu dzejoḷu vidū kā kaut kas monumentāls, nedz drukāta laikrakstu pirmajās lappusēs vai uzdota skolēniem mācīties no galvas.

\section{Pirmie pieticīgie rezultāti}

Atgriezīsimies 1940. gada nogalē. Jau minētā latviešu mākslas dekāde bija paredzēta 1941. gada pavasarī - PSRS republiku mākslas dekādes notika kopš 1936. gada, un "katrai dekādei bija jānoslēdzas ar "valdības koncertu" un neiztrūkstošu Stalina slavinājumu ìpaši veltītā kompozīijijā". ${ }^{15} \mathrm{Nav}$ īsti skaidrs, kāpēc tieši padomju Latvija bija izvēlēta par pirmo no t. s. jaunajām republikām (1940. gadā okupētajām teritorijām), kurai tika izrādīts tāds "gods". Padomju Latvijas funkcionāri, pateikdamies par izvēli, cik vien iespējams, centās izpatikt Maskavai: "Tikai ìsu laiku mēs esam varenās Padomju Sociālistiskās Savienības sastāvā, bet jau tik nopietns un ievērojams uzdevums."16 Darbiem ieilgstot, dekādes sākuma termiņš tika pārcelts uz septembri, tad - decembri. Dekādes sagatavošana ir nopietni izpētīta, veltot uzmanību arī nepatīkamai parādībai, kuru Maskavai demonstrēja vairāki izcili latviešu mākslinieki (piemēram, Teodors Reiters (1884-1956) ierosināja sacerēt speciālu kantāti, kura būtu "[...] silts LPSR rokas spiediens PSRS un vinas tautām". ${ }^{17}$ Speciāla brigāde, kura no Maskavas bija ieradusies vadīt dekādes sagatavošanu, dažbrīd bija pat pārsteigta par latviešu gatavību pakḷaut savu kultūru nevajadzīgai paškritikai. Dekādes sagatavošana uzlika Latvijas aktieriem un komponistiem milzīgu slodzi, tai skaitā - t. s. politiskās audzināšanas jomā; "neizaudzināti” mākslinieki nevarēja godam pārstāvēt padomju 
Latviju). ${ }^{18}$ Dekāde nebūtu bijis vienīgais lai arī noteikti lielākais - gatavojamais pasākums. Herberts Līkums (1902-1980) 7. decembrī paziņoja:

"Mākslas lietu pārvalde ir izstrādājusi VK (b) vēstures un Latvijas darba l̦aužu cīnu vēstures tematus tēlotājai mākslai, pēc kuriem mākslinieki varēs veidot darbus grandiozai 1942. gada izstādei "Mūsu Dzimtene", kas notiks sakarā ar lielās Oktobra revolūcijas 25 gadu atceri kopēji visām republikām Maskavā. Šai izstādei mobilizēs visus radošos spēkus."19

Izstādes temati bija "Latvijas proletariāta atsvabināšana 1940. gada 17. jūnijā", "Sarkanarmijas ienākšana Latvijā", "Tauta apsveic Sarkanarmijas daḷas" u. c. ${ }^{20}$ To, kas no tēlotājas mākslas pārstāvjiem tika gaidīts, labi atklāja mākslinieka Kārḷa Buša vērtējums par pirmo Latvijas PSR tēlotājas mākslas izstādi Rīgā - to bija organizējusi minētā Mākslas lietu pārvalde, konkrēti - Rūdolfs Pinnis. ${ }^{21}$ Izstāde notika pilsētas Mākslas muzejā 1941. gada janvārī, un tajā piedalījās 160 mākslinieki ar 290 darbiem.

"Padomju iekārtas nodibināšana, darba l̦aužu atbrīvošana no kapitālistisko izmantotāju varas, dziļas pārmainas visās dzìves nozarēs un sabiedriskās attiecībās, škiet, pārāk maz ietekmējušas arī tos māksliniekus, kuri savus darbus darinājuši jaunajā laikā. Lielāka uzmanība turpmāk veltāma figurālai glezniecībai, it sevišk̦i vēsturiskam žanram, jo vēsturiskā glezniecỉba ir tas glezniecības veids, kas vislabāk spēj iemiesot jaunu saturu, jaunas idejas."22

K. Piṇna lielāko nepatiku izraisīja klusās dabas - viṇaprāt, "vieglākā glezniecības veida" - žanrs latviešu glezniecībā: "Kā tipisks buržuāzisks mantojums ar niecīgu sociālo un sabiedrisko nozimi, klusā daba vēl joprojām saista daudzus mūsu māksliniekus." Kā piemēru viṇš min Leo Svempu: "[...] gleznieciski augstvērtigu darbu, diemžēl, kluso dabu - "Puḳes", uzrāda Leo Svemps."23 Kritika - tiesa, ne brutāla vai iznīcinoša, tika veltīta Tukuma māksliniekiem:

"Stipra modernās franču glezniecības ietekme jūtama A. Artuma un K. Neiļa darbos. Nav noliedzama šo gleznotāju laba gaume un krāsu izjūta, bet glezniecìba, kurai maz kopēja ar reālo dzīvi, kura stāv pārāk tālu no ìstenïbas, un nav patiesa savā būtïbā, nesaskan ar mūsu laika prasībām." ${ }^{24}$

Tomēr viņa galveno kritiku izraisīja nevis minētie talantīgie mākslinieki, bet kāds primitīvs pielīdējs Kārlis Eglītis, kurš bija uzgleznojis divus "pareizus" darbus "Sarkanarmijas sagaidīšana" un "1940. g. 17. jūnijs": "[...] viņš gan izvēlējies jaunu tematiku, bet nav pratis savu uzdevumu atrisināt. Neveikli veidotās figūras un to nejaušais novietojums gleznās, neizjustas krāsas, nespēja iedzilināties notikumu būtībā, raksturo gleznas no pirmā acu uzmetiena". ${ }^{25}$ Tāds pats primitīvisms literatūrā izraisīja pat Annas Sakses (1905-1981), "Cīṇas" kultūras nodaḷas vadītājas un faktiski neievērojamas literātes, kritiku. Piemēram, izvērtējot Indriķa Lēmaņa stāstu "Traktoriste Kristīne", viṇa ar ironiju rakstīja:

"Kristine ir budžu izkalpinātas laukstrādnieces shēma, saimniece - budžu sliktāko ipašǐbu kopsavilkums. Kad Kristinei par daudz pāri nodarìts, tā aiziet. Bet tad, neparādījis vinas tālākās gaitas un pārveidìbas, autors to uzsēdina uz traktora un Kristine smaidìdama iebrauc agrākās darba vietas tirumus." 26

(Pati A. Sakse nedaudz vēlāk radīs tikai nedaudz mazāk primitīvus tēlus, sākot ar savu pirmo darbu padomju okupācijas laikā - stāstu par audējām "Lūzums", kuru 
“Cīṇa” sāka publicēt 1941. gada 27. aprīlī.) Savukārt, raksturojot dzejniekus Jūliju Vanagu (1903-1986), Andreju Balodi (1908-1987) un Valdi Luksu (1905-1985), viṇa atzīmēja: viṇu dzeja pagaidām atgādina tikai "[...] mākslinieciskus plakātus - tā uzmudina, bet neiesilda". ${ }^{27}$

Visdažādākie motīvi noteica gleznotāju un grafiķu nostāju pret okupācijas varas prasībām. Vēlēšanās kaut kā nopelnīt, nevis idejiskie motīvi laikam bija galvenais iemesls, kāpēc Latvijas izcilākie grafiḳi Oḷǵgerts Ābelīte (1909-1972), Aleksandrs Junkers (1899-1976), kā arī vairāki gleznotāji un pat tēlnieks Kārlis Zemdega pieteicās radīt PSRS valstsvīru portretus, kuri bija jāizvieto visur ${ }^{28}$ (protams, O. Ābelītem un A. Junkeram labi noderēja zīmēšanas prasme, kuru viniem Rīgas Tautas augstskolā bija iemācījis Romans Suta (18961944), ${ }^{29}$ - neprasme zīmēt, nevis nevēlēšanās radīt komunistu vadoṇu portretus būs par cēloni tam, ka pat ievērojami gleznotāji netiks pie izdevīgiem pasūtījumiem). Savukārt divu lielisku Tukuma gleznotāju Anša Artuma (1908-1997) un Kārḷa Neiḷa (1906-1991) - nodeva jaunajai varai, proti, A. Artuma "Sarkanarmijas ienākšana" un K. Neiḷa "Revolūcijas svētki Tukumā", tāpat vairāku citu gleznotāju darbi, t. sk. no Mākslas akadēmijas atlaistā Augusta Annusa glezna "Cīṇa pie Aleksandra vārtiem", ${ }^{30}$ droši vien bija nekā cita kā baiḷu radīta. Tā bija vienkārši izdzīvošana. Tehniski vismazākās problēmas apmierināt sociālistiskā reālisma prasības bija klasiskā akadēmisma pārstāvim Jānim Robertam Tillbergam (1880-1972) - vienam no latviešu glezniecības ievērojamākajiem pārstāvjiem. Kad 1940. gada jūnijā Latviju okupēja PSRS, R. Tillbergs bija "[...] nodevies arī intensīvām latviešu vēstures studijām un, starp citu, strādā pie komplicētas kompozīcijas, kas attēlo loti dramatisku notikumu ar hercoga Jēkaba sievu Jelgavas pilī". ${ }^{31}$ Tēmas izvēle nebija negaidìta - Kurzemes hercogiste, un īpaši hercogs Jēkabs, Kārḷa Ulmaņa autoritārā režìma gados tika cildināta kā latviešu valsts, bet K. Ulmanis - kā Jēkaba lielo darbu mantinieks (1940. gada sākumā tika nolemts sarīkot sacensību "[...] dailliteratūrā, tēlotājā mākslā un mūzikā par tematu no hercoga Jēkaba laikmeta"). ${ }^{32}$ Sākoties okupācijai, šādas tēmas bija pilnīgi neatbilstošas politiskām prasībām. R. Tillbergam nācās slēgt arī savu populāro privātstudiju, un viṇa tradicionālā publika - Latvijas sabiedrības augšslāṇi - vairs nedomāja par saviem portretiem: bija citas, daudz dramatiskākas rūpes. Tomēr R. Tillbergs vismaz materiāli bija nodrošināts - viṇa labs paziņa arhitekts Eižens Laube uzaicināja vinu uz Latvijas Universitāti par Arhitektūras fakultātes tēlotājas mākslas darbnīcas profesoru. ${ }^{33}$ Nebūdams ne mazākā mērā kreiss, lai neteiktu otrādi, R. Tillbergs nesteidzās savos darbos piemēroties okupācijai: jau minētajai Latvijas PSR mākslas izstādei viņš piedāvāja pilnīgi apolitisku gleznu "Jūra" (ainavas viņš gleznoja diezgan reti, bet šì glezna tika izstādīta līdzās tādiem patiesiem briesmu darbiem kā Augusta Pupas "Ulmaņa bendes" un "Fašistu cietumā"). ${ }^{34}$ Tomēr 1941. gada pavasarī R. Tillbergs laikam bija secinājis, ka bez smagām ideologiiskām nodevām jaunajā režīmā neizdzīvot, sekoja aktīva pielāgošanās un pilnīgas neveiksmes. Tā viņš nesekmīgi piedalījās 1. maija noformējuma konkursā, piedāvāja pat tik odiozu darbu kā "Jāṇa Kalnbērziṇa iznākšana no cietuma”, kas tika noraidìts, plānoja darbu par Leonu Paegli cietumā, neaizmirsa arī Frīdrihu Engelsu (Friedrich Engels), taču galu galā pilnīgi pareizi secināja, ka jāḳeras klāt pašam Stalıinam: vina uzgleznotais Stalina portrets patiešām bija atbilstošs sociālistiskajam reālismam - stingam akadēmiskam pompozumam, ${ }^{35}$ kas arī tika no māksliniekiem prasītss ${ }^{36}$ (līdz tuvīnajai vācu okupācijai darbs atradās Latvijas Universitātes izstāžu zālē, bet tad kaut kur pazuda). 


\section{lenesīgā politiskā tēlniecība}

Tēlniecība laikam ir visvairāk politizētais tēlotājas mākslas veids: tie, kuriem ir vara, vienmēr ir vēlējušies sevi iemiesot bronzā un marmorā; tēlnieki vienmēr ir centušies iegūt ienesīgus pasūtījumus. Tas bija skaidri redzams arī K. Ulmaņa autoritārā režīma gados. Zemākā, neprasmīga amatierisma līmenī tas iemiesojās K. Ulmaņa un Jāṇa Baloža krūšutēlos, kuri bija pasūtīti mazpazīstamam tēlniekam Rūdolfam Feldbergam - piemēram, $65 \mathrm{~cm}$ augsts balts vai bronzas krāsas ǵipša krūšutēls maksāja 16 latus, taču galu galā tie izrādījās l,oti nepopulāri - J. Baloža krūšutēls tika pat atzīts par pilnīgu neveiksmi; pretēji iecerei saražot vismaz 250 krūšutēlus katru mēnesi, tika izgatavoti tikai 365 K. Ulmaņa un 238 J. Baloža krūšutēli. ${ }^{37}$ Citā, augstākā līmenī darbojās pazīstami vai pat izcili latviešu tēlnieki. Līdz šim ir apzinātas četras K. Ulmaņa statujas un vismaz pieci krūšutēli: to autori ir Rihards Maurs (1888-1966), Jānis Briedis (19021953) un Aleksandra Briede (Kalniņa) (1901-1992) (vinii abi kopā izveidoja trīs K. Ulmaṇa statujas), Kārlis Zāle (18881942), Burkards Dzenis (1879-1966) un Teodors Zaḷkalns (1876-1972), kurš izveidoja gan lielu K. Ulmaņa krūšutēlu, gan vēl lielāku statuju, kura tika izstādīta Latvijas mākslas izstādē Kopenhāgenā, Dānijā, un kuru dāṇu prese raksturoja kā kolosālu savos izmēros (tās augstums bija 2,8 metri). T. Zaḷkalns arī finansiāli bija îsts laimes luteklis - kā redzēsim, jebkurā režīmā; par šo statuju viņš saṇēma 2500 latus. ${ }^{38}$ Dāsnie pasūtījumi padomju okupācijas laikā nedz Jānim un Aleksandrai Briežiem, nedz T. Zaļkalnam neradijja nekādas morālas dabas problēmas. Kas bija iecerēts pirmajā okupācijas gadā, un kas tika īstenots? Vienā no darbiem, kas tika publicēts padomju Latvijā, rakstīts, ka bez jau pieminētās statujas Rainim - tiesa, tas tika saukts par pieminekli, bijis iecerēts "celt pieminekḷus leǵendārajiem sarkanajiem latviešu strēlniekiem [...] dainu tēvam Krišjānim Baronam un c.”. ${ }^{39}$ Apstiprinājumu šim apgalvojumam pagaidām nav izdevies atrast. Daži vārdi īpaši jāsaka par to, vai tobrīd varēja pastāvēt iecere uzcelt pieminekli sarkanajiem latviešu strēlniekiem. 1940./1941. gads bija l̦oti nelabvēlīgs sarkano latviešu strēlnieku pieminēšanai: visi strēlnieku komandieri, ieskaitot Jukumu Vācieti, bija Padomju Savienībā nogalināti, un bija sākusies viṇu piemin,as izdzēšana; vienā no 1940. gadā Maskavā izdotajiem darbiem, kurš bija veltīts kreiso eseru dumpim 1918. gada jūlijā, viṇi pat nebija pieminēti, lai gan dumpja apspiešanā latviešu strēlniekiem J. Vācieša vadībā bija izškiroša loma. ${ }^{40}$ (Nenosaucot J. Vācieti vārdā, vinšs tiks pieminēts kā Pulkvedis, bet tikai pēc kara, 1948. gadā, A. Čaka dzejolī "Kremlī pie L̦enina"). ${ }^{41}$ Padomju Latvijā par viniem paretam un ìsos vārdos tika rakstīts presē, arī uzmanīgi izvairoties minēt kreiso eseru dumpja apspiešanu ${ }^{42}$ un, protams, nenosaucot nevienu komandieri vārdā - varēja likties, ka ir tikai divi vai trīs latviešu sarkanie strēlnieki ar vārdu. Viens no tiem bija latviešu komunists Pēteris Plēsums, ${ }^{43}$ kurš līdz 1931. gadam bija dzīvojis Padomju Savienībā, bet tad bija atsūtìts nelegālam darbam uz Latviju un līdz ar to izvairījies no Staḷina Lielā terora; tagad viṇš bija LPSR Augstākās Padomes Prezidija priekšsēdētāja Augusta Kirhenšteina vietnieks un kopš 1941. gada marta arī LKP CK sekretārs. ${ }^{44}$ Otrs bija Roberts Neilands, arī LKP CK sekretārs ar līdzīgu biogrāfiju, ${ }^{45}$ un kāds nevienam nezināms latgalietis Varfolomejs Rubuls, kurš bija darbojies LKP Ludzas apriņkii $\bar{i}^{46}$ un tagad tika ievēlēts PSRS Augstākajā Padomē kā šķietams latgaliešu interešu pārstāvis. ${ }^{47}$ Laikam vienīgais publiskais pasākums latviešu sarkanajiem strēlniekiem bija viņiem veltīta diena Rīgas pilsētas 7. bibliotēkā, 
tā bija paredzēta 1941. gada 30. maija $\bar{a}^{48}$ (kā īsti tā notika, nav zināms). Škiket, ka tas, ko Maskava aț̣āva, bija saistīts ar gaidāmo Vissavienības lauksaimniecības izstādi Maskavā, kurā Baltijas padomju republikām bija atvēlēts viens kopīgs paviljons, kura sienas bija jānoklāj gan ar panno gleznojumiem, ${ }^{49}$ gan gleznām ("Pēc Latvijas gleznotāju grupas skicēm top liels audekls, kura temats "Padomju Savienibas jaunās robežas rietumos ir neien,emamas"')). ${ }^{50}$ Viens no šādiem gleznojumiem būtu veltīts "latviešu sarkaniem strēlniekiem Oktobra revolūcijas laikā". ${ }^{51}$ (Cita informācija liecināja, ka latviešu sarkanie strēlnieki tiktu attēloti Rīgā 1919. gada 3. janvārī - padomju Latvijai nodibinoties; tas varētu likties sīkums, taču ar to vinu loma tika pazemināta, lokalizēta, neattēlojot vinus galvaspilsētā Petrogradā vai kādā no pilsoṇu kara izškirošajām frontēm). ${ }^{52}$ Izstādi tomēr nepaspēja atklāt, jo sākās Vācijas un PSRS karš. Piemineklis latviešu sarkanajiem strēlniekiem neietilpa tajā, ko piẹ̦āva Maskava, un tiks uzcelts tikai trīsdesmit gadus vēlāk.

Interesantu liecību mākslas vēsturniekam Vaidelotim Apsītim 1986. gada 19. decembrī, kad viņš strādāja pie grāmatas par K. Zāli, sniedza tēlnieks Kārlis Baumanis: K. Zāle, būdams jau smagi slims un dzīvodams Inčukalnā, 1940.-1941. gada ziemā veidojis plastilīnā latviešu sarkanā strēlnieka figūru: "Tādus es vinus Petrogradā redzēju," teicis K. Zāle. ${ }^{53}$ Strēlnieks esot bijis attēlots ar šauteni pāri plecam un granātu rokā. Nav šaubu, ka K. Zāle Krievijas revolūcijas laikā ne vienu vien reizi bija redzējis latviešu sarkanos strēlniekus Petrogradā; ${ }^{44}$ vēl pat 1919. gada otrajā pusē, kad komunistu vara bija gāzta Latvijas lielākajā daḷā, viņš vēl bija kādu laiku strādājis padomju Latvijas Izglìtības komisariātā Rēzeknē un laikam arī pie kāda pieminekḷa projekta - tajā bija attēlots komisārs un strādnieku grupa. ${ }^{55}$
Nevienā citā avotā tomēr nav izdevies atrast apstiprinājumu K. Baumana teiktajam par K. Zāles iecerēm pirmajā padomju okupācijas gadā. Ar K. Zāli lieta nav skaidra, taču daudz skaidrāka tā ir ar citiem tēlniekiem, kuri sāka veidot Vladimira L,enina (Vladimir Lenin) un Stalina skulptūras. Pirmais pie L̦eninina skulptūras k̦ērās izcilais latviešu tēlnieks Emīls Melderis (īst. v. Jēkabs Emīls Millers, 1889-1979), kurš bija radījis tādus meistardarbus kā Pāvila Rozī̌sa portrets, piemineklis Latvijas Brīvības cīnās kritušajiem Valkā, 1933. gada šedevrs "Puikas" u. c. Vēl pavisam nesen, 1939. gadā, latviešu mākslas vēsturnieks Jānis Dombrovskis pamatoti bija E. Melderi nosaucis par dižo torņakalnieti, jo tur viņš dzīvoja. ${ }^{56}$ E. Melderis tika uzaicināts strādāt Mākslas akadēmijā (kamēr K. Zāle no tās tika atlaists) un, iespējams, pateicībā par to - pirms tam viṇš bija strādājis par skolotāju Teodora Zeiferta pamatskolā - ķērās pie L,enina skulptūras, taču pabeigt to pirmajā okupācijas gadā nepaspēja. ${ }^{57}$ Pēc kara, kad padomju okupācija tika atjaunota, viņš izveidos vairākas L,eņina skulptūras, tāpat kā Pētera Stučkas, Friča Rozinna un Raiṇa tēlus, tomēr mūža nogalē, 1968. gadā, radītā skulptūra "Rainis un Stučka Slobodskā" jau atstāja diezgan nožēlojamu iespaidu. ${ }^{58}$ E. Melderis L̨eņina skulptūru izveidot nepaspēja, taču nelielu L,enina bisti laikam paguva izveidot J. un A. Brieži, pie tam J. Briedis, vāciešiem ienākot, šo nelielo darbu bija ieracis zemē, tā izglābjot no iznīcināšanas $^{59}$ (tas, protams, abu mākslinieku statusu, padomu okupācijai atjaunojoties, tikai paaugstināja). ${ }^{60}$ 1941. gadā abi tēlnieki izveidoja arī milzīgu ǵipša skulptūru "Robežsargs ar suni”, kas tika izvietota netālu no Brīvības pieminekḷa, "[...] lai uzskatāmi demonstrētu, kam ir vara un noteikšana"61 (arī šì skulptūra pārdzīvos karu un pēc tam vēl ilgi, līdz pat 60. gadu vidum, atradīsies kāda atpūtas nama pagalmā 
Jūrmalā). ${ }^{62}$ Pēckara gados abi Brieži veidos gan Stalina, gan L̦eñina tēlus, un izdomas kalngalus A. Briede - patiešām talantīga tēlniece - sasniegs 1969. gadā, kad, gatavojoties L̦eņina 100. dzimšanas dienai, izveidos granīta "Ḷeņinu - sapṇotāju” (!), kas tiks augstu novērtēts ${ }^{63}$ un apbalvots ar LPSR Valsts prēmiju.

1941. gada 1. aprīlī tika noslēgts līgums ar T. Zalıalnu par 1,40 m augstu Stalina krūšutēlu bronzā; tas bija jāizgatavo līdz 1. jūlijam, un par to vinam bija jāsaṇem 3000 rbl, ${ }^{64}$ Lai arī izveidot minēto krūšutēlu līdz padomju pirmā okupācijas gada beigām tēlnieks nespēja, iespējams, avansu par iecerēto darbu viņš saṇēma - tā bija ierasta prakse padomju laikā (T. Zaḷkalns bija arī to nedaudzo latviešu kultūras mākslinieku vidū, kuriem pirmajā okupācijas gadā tika pieškirta mūža pensija; tiesa, nav zināms, cik tā bija liela un vai to jau sāka izmaksāt 1941. gadā). ${ }^{65}$ Tāpat kā K. Ulman,a statuja nebija šķērslis T. Zaḷalnam veidot Staḷina statuju, tāpat Staḷina krūšutēls nebija par šḳērsli jaunajā, vācu, okupācijā sākt veidot Lielvācijas vadoṇa Ādolfa Hitlera (Adolf Hitler) bisti, san,emot par to loti ievērojamu summu - 4300 reihsmarku: šis darbs "varēja kḷūt par vienu no nedaudzajiem nacistu okupācijas laika totalitārās mākslas paraugiem Latvijā" ${ }^{66}$ Lai arī darbs laikam netika pabeigts, honorāru tēlnieks tomēr bija saṇēmis.

\section{"Pretim Saulei”}

Tā saucās pirmā filma (apakšvirsraksts "Filma par Padomju Latviju"), kas tika uzn,emta pirmajā okupācijas gadā: pilnmetrāžas dokumentāla filma, kura bija pabeigta 1941. gada marta beigās ${ }^{67}$ un no 1 . maija parādījās uz ekrāna:

"Filma sākas ar atbrīvotās tautas gavilēm ielās, sagaidot Sarkano Armiju, apsveicot atbrìvotos cietumniekus. Tukšās cietuma kameras stūrī paliek ar veseri sadauzìtās kandalas. Visā Rìgā mītini un demonstrācijas. Un tālāk - Maskava sagaida latviešu delegāciju ar prof. Kirchenšteinu priekšgalā, kas ieradušies uz PSRS Augstākās Padomes vēsturisko sesiju."68

Filmas režisors un scenāristi - Iḷja Kopalins (Il'ja Kopalin) un M. Ceitlins (M. Ceitlin) - bija no Maskavas, bet operatoru vidū bija arī pazīstamais latviešu operators Eduards Kraucs (1898-1977), mūziku bija uzrakstījis Jānis Medinšs. ${ }^{69}$

"Latvijas nesenās dzives kadri: lauku un pilsētu bezdarbnieki, tukša, pamesta rūpnicas ēka. Bet pretstatāa - greznā, bezrūpigā bagātnieku jūrmala, zalıumu skautas villas, pludmales prieki. Un vēsturiskais lūzums Latvijas likteños. Kadrs aiz kadra, kuru sižetos lemts ietvert vārdu "pirmais": pirmā vaga pēc zemes pārdalǐšanas, pirmā traktoristu pamācība, pirmie klausitāji krievu valodas kursos" -

tā filma tika raksturota padomju Latvijas kino vēsturē. ${ }^{70}$ Lai cik lielā mērā okupētās Latvijas prese jau nebija kontrolēta, tomēr zināma kritika par filmu vēl tika piel̦auta:

"[...] filma neaptver visus mūsu tautas lielos vēsturiskos notikumus un nedod pilnigu ieskatu tautas dzivee. Redzam gan atseviškas ainiñas no nelegālās revolucionāru darbibas, redzam sagruvušos fabriku korpusus, kas tagad Padomju Latvijas laikā tiek atjaunoti, un tajos rit spriega darba dzive, bet pavisam maz filmā redzami raksturīgie tautas tipi, sadzìves ainas. Tāpat nav parādìta ìsti neviena lauku sēta. Visus šos trūkumus nenoliedz ari filmas režisors, bet aizrāda, ka tie nav bijuši novēršami filmas radī̌anas darbā, kas iekritis taisni ìsajās un tumšajās rudens un ziemas mēnešu dienās. 
Tādos apstākḷos uznêemumi ārpus studijas ir gandrìz neiespējami. Nākamā mūsu dokumentārā filma neapšaubāmi būs labāka skatitāju prasību apmierinātāja kā š̉”. ${ }^{71}$

Jau 1940. gada novembrī bija izsludināts arī scenāriju konkurss mākslas filmām. 1941. gada pavasarī darbs bija pavirzījies pie trim scenārijiem - F. Rokpeḷna scenārija par 1940. gada 17. jūniju, Viḷa Lapenieka (1908-1983) - par komponista Emila Dārziņa dzīvi ("Melanholiskais valsis"), bet laikam vistālāk bija pavirzījies darbs pie scenārija "Kad atausa rīts" par komunistisko pagrīdi Latvijā laikā no 1939. gada oktobra līdz 1940. gada 17. jūnijam. ${ }^{72}$ Tā autors bija krievu rakstnieks Nikolajs Virta (Nikolaj Virta), kurš tikko bija saṇēmis Staḷina prēmiju par romānu "Vientulība": "[...] galvenās romānā darbojošās personas ir šķiras ienaidnieki - kulaki un eseri, un apbrīnojami skaidrs un reljefs ir Virtas šo tipu zimējums". ${ }^{73}$ Ienaidniekus, protams, N. Virta veikli attēlotu arī filmas scenārijā. Tik nopietns bija viņa uzdevums, ka scenārija lasīšanai un apspriešanai 1941. gada maija otrajā pusē Maskavas kinostudijā tika sasaukta PSRS kino elites apspriede, kurā piedalījās gan Rīgā dzimušais lielais režisors Sergejs Eizenšteins (1898-1948), gan tālaika padomju populārākais kino režisors, arī tikko ar Stalina prēmiju apbalvotais Grigorijs Aleksandrovs (Grigorij Aleksandrov, 1903-1983), kurš bija iesācis muzikālo filmu mākslu PSRS ("Jautrie zēni", "Cirks", "Volga - Volga”, "Gaišais cel̦š”), veikli aizn,emoties Holivudas tehniskos paṇēmienus, kurus viņš un S. Eizenšteins bija redzējuši dzīvē, 30. gadu sākumā uzturoties ASV.

\footnotetext{
"Scenārija sižeta linijas vijas ap vadošā pagrīdes darbinieka Žaña Strautnieka, Latvijas Komunistiskās partijas Centrālās komitejas locekḷa, un vina tuvākā palìga komunista strādnieka Pētera Eglǐša un komjaunietes strādnieces Ernas Lindes darbu." 74
}

Skaidrs, ka nevarēja iztikt bez ienaidniekiem:

“Ľoti spilgti scenārijā tēlo plutokrātiskās iekārtas vaditāju nodevïbas, kas pārdeva latviešu tautas intereses. Dalı̄eji veselas epizodes būs veltitas Latvijas, Igaunijas un Lietuvas armijas pārstāvju slepenām apspriedēm Siguldas pilī, kad buržuāziskās Latvijas vaditāji rupji pārkāpa savstarpējās palidzibas paktu PSRS un kala pretpadomju bloku Baltijä. "ᄁ5

Visi klātesošie slavēja scenāriju; par filmas režisoru bija izraudzìts pazīstams padomju mākslinieks Boriss Barnets (Boris Barnet, 1902-1965), kura pirmā skaņu filma "Nomale" (1933) tika uzskatīta par paraugu revolucionāru attēlošanai. Tika cerēts, ka filmu uzņems vēl 1941. gadā, bet ar to laikam bùtu bijis par maz: padomju Latvijas vadītāji Vilis Lācis un Žanis Spure bija izvirzijuši ideju, ka nepieciešams uzṇemt arī otro sēriju, "kurā parādītu varoņus padomju varas apstākḷ un viņu dalïbu sociālisma celtniecībā". ${ }^{76}$ Iespējams, priekšdarbi arī tika uzsākti - vismaz par režisoru laikam tika izraudzīts Aleksandrs Rusteikis (1882-1958), ${ }^{77}$ tas pats, kura spēlfilma "Aizsprosts" bija aizliegta. Viņš bija "reabilitējies": klusējot vairākus mēnešus, palicis bez darba un, iespējams, bez lielākiem iztikas līdzekḷiem, 1941. gada 10. martā A. Rusteiķis bija uzrakstījis vēstuli LKP Rīgas pilsētas komitejai, bagātīgi nomaksājot nodevu jaunajam režīmam. Viṇš rakstīja, ka Latvijā esot dzīvojis

"manai sirdij svešā pasaulē, kurā es nevarēju atrast apmierinājumu [...] pussatrunējušajā kapitālistiskās "labklājības" pasaulē [...] Izrauties no šì "purva" nebija iespējas [...] Bet notika tas, par ko es varēju tikai sapñot. Atnāca atbrīvotāji - Lielā Padomju Savienība - varenais kultūras virzìtājs. Lai dzìvo mana dzimtene [PSRS], 
varenā un neaptveramā [...] Lai plìvo pār to sociālisma karogs kā pasaules revolūcijas simbols [...] Ilgu mūžz̆u mūsu vadonim biedram Stalinam".

Kāds Komunistiskās partijas funkcionārs, kurš to lasīja, nevarēja noticēt tik lielai pielīšanai un pierakstīja klāt: " $A r$ varu grib izlikties lojāls", ${ }^{78}$ taču A. Rusteikis patiešām bija labs režisors, un laikam bija nolemts vinu izmantot, taču līdz Vācijas uzbrukumam PSRS bija palicis pavisam nedaudz, un nekas liels netika paveikts (nepaspējis iegūt nekādu atzinību no padomju varas, pēc kara, okupācijai atjaunojoties, viņš tika pavisam aizmirsts, iespēja darboties padomju kino vinam netika dota, un viņš strādāja par fotogrāfu Jūrmalā līdz savai nāvei 1958. gadā). ${ }^{79}$ Lai gan literatūrā ir minēts, ka bija iecerēta arī filma "Valmieras puikas" pēc P. Rozī̌sa populārā romāna motīviem, ${ }^{80}$ škiiet, nekādi priekšdarbi netika uzsākti. Vienīgā mākslas filma, kura 1941. gada 13. jūnijā, īsi pirms kara sākuma, parādījās uz ekrāna, bija režisora Valdemāra Pūces filma "Kaugurieši". ${ }^{81}$ Filmas uzņemšanai bija diezgan gara vēsture, arī atspoguḷojot politisko pārmaiṇu ietekmi. Lēmums par filmas uzṇemšanu pēc Kārl̦a Zariņa populārā romāna tika pieņemts vēl neatkarīgās Latvijas laikā, 1940. gada martā, ${ }^{82}$ bet pirmie ārskata kadri Valmieras tuvumā tika nofilmēti tieši Latvijai liktenīgajā 17. jūnijā. Varbūt tāpēc, ka tajā dienā operatoru vidū nebija galvenā operatora Valdemāra Upīša (1904-1986), bet varbūt tāpēc, ka šajā dienā operatorus nodarbināja citas domas (iespējams, tad, kad filmētāji devušies uz Valmieru, pretim braukuši padomju tanki), ${ }^{83}$ pirmie nofilmētie kadri tika atzīti par mazvērtīgiem, lai arī darbu vairāk iekavēja nepieciešamība korig̣ēt scenāriju atbilstoši jaunajām prasībām - tas nozīmēja nepieciešamību vairāk uzsvērt šḳiru cīṇu. ${ }^{84}$ Tas tika izdarīts, un rudenī filmēšana ieguva lielus apmērus - tā tika uzskatīta par pirmo latviešu revolucionāro lielfilmu, kurai netika taupīti līdzekḷi: filmā tēloja 40 aktieri, 200 statisti un 100 tehniskie darbinieki ("tautu" tēloja pat kādas Rīgas patversmes nespējnieki, kuri pie tam vēl tika ieg̣ērbti "etnogrāfiskos skrandainos tērpos", "tautai" bija jāizskatās galīgi nomocītai). Origininālmūziku rakstīja Bruno Skulte (1905-1976), filmas mākslinieks bija R. Suta. 1940. gada decembra sākumā filmēšana tika pabeigta, bet viss darbs 1941. gada maija vidū, un 16 . maijā filmu aizsūtīja uz Maskavu, lai ieskaņotu krievu valodā. ${ }^{85}$ Tā bija pirmā latviešu padomju aktierfilma, kurā bija īpaši uzsvērtas škiru pretišķības: "Baronu pili lìksmo - zemnieki vergo kungu rijās [...]"86 Sākoties vācu okupācijai, filmas negatīvi tika iznīcināti, tomēr trīs eksemplārus izglāba Rīgas kinostudijas darbinieki, un filma no jauna parādījās uz ekrāna 1946. gada aprīlīi. ${ }^{87}$

Traơisks izvērtās filmas mākslinieka R. Sutas liktenis - viņš tik lielā mērā bija satuvinājies ar padomju režìmu, ka, vācu uzbrukumam sākoties, brīvprātīgi bēga uz PSRS iekšieni un galu galā nonāca Gruzijā, kur strādāja par mākslinieku Tbilisi kinostudijā. Padomju Gruzijas realitāte laikam bija par traku pat kreisi orientētajam māksliniekam. 1943. gadā viņš tika arestēts par viltotu pārtikas kartiņu izgatavošanu un izmantošanu. Vispirms viņš saṇēma 10 gadus cietumā, bet 1944. gadā tika tiesāts vēlreiz, vinam tika piespriests nāves sods, kas tika izpildīts 1944. gada 19. jūlijā. ${ }^{88}$ Latviešu māksla zaudēja vienu no saviem talantīgākajiem, vispusīgākajiem un īpatnējākajiem māksliniekiem.

\section{Arī Čaks...}

Lai gan tālajā 1920. gada 15. novembrī A. Čaks atradās bēgḷu gaitās Krievijā, viņš bija iestājies komunistu partijā Penzā izvietotā 25. rezerves kājnieku pulka 
partijas organizācijā un tuvākā gada laikā mācījās Penzas partijas skolā un darbojās kā komunistisks propagandists - vietējās avīzes Kommunističeskij putj redaktors. ${ }^{89}$ Kad blakus esošajā Tambovas guberņā notika Aleksandra Antonova (Aleksandr Antonov) vadītā zemnieku sacelšanās pret komunistiem, A. Čaks piedalījās tās brutālajā apspiešanā, ${ }^{90}$ tomēr, par laimi, 1922. gadā nolēma atgriezties Latvijā, un, lai arī padomju Krievijā bija raksturots kā "noturīgs, aktivs komunists", ${ }^{11}$ Latvijā viņš sakarus ar komunistiem neuzṇēma un bija mēreni kreisi orientēts rakstnieks, kurš 1933.-1934. gadā neilgi bija bijis pat Latviešu sociāldemokrātiskās strādnieku partijas biedrs. ${ }^{92} \mathrm{~K}$. Ulmaņa autoritāro režīmu vinš̌ pārdzīvoja vairāk nekā labi: tikai nedaudz tika palaboti "Mūžīibas skartie" "sarkanās gvardes" vietā tagad bija "brīvības gvarde", "sarkanā avangarda" vietā "brīvības avangards", "sarkano strādnieku karogu" vietā - "varenie strādnieku karogi". 1940. gada janvārī par šo lielo darbu viņš saṇēma Annas Brigaderes prēmiju: "1940. gada sākumā A. Čaka dzejnieka popularitāte sasniedz savu augsti." "93 Taču tieši "Mūžības skartie", par kuriem bija saņemta cienījamā un pelnītā balva, pēc Latvijas okupācijas 1940. gada 17. jūnijā radīja dzejnieka sirdī pavisam citas jūtas - bailes no jaunās varas iespējamās atriebības gan par pašu darbu, gan par balvu, kura tika uzskatīta par loti nacionāli orientētu: “[...] jālūdz Dievs, lai visi pēc iespējas ātrāk aizmirstu "Mūžǐbas skartos"”. ${ }^{94}$ Pirmos okupācijas mēnešos, kad daudzi rakstnieki jau slavēja jauno varu un Stal̦inu, ${ }^{95}$ A. Čaks bija kluss, acīmredzot arī spēcīgi pārdzīvojot to, ka viņš - lielākais no dzīvajiem latviešu dzejniekiem - pat netika uznemts par biedru, bet bija tikai kandidāts jaunizveidotajā Latvijas PSR Rakstnieku savienībā (par pilntiesīgu biedru A. Čaks kḷūs tikai 1941. gada 1. jūnijā, kad jau būs nomaksājis - kā redzēsim turpmāk - ievērojamas nodevas jaunajai varai). Pirmie dzejoḷi parādījās tikai 1941. gada sākumā, kad, iespējams, A. Čaks, vēlēdamies tikt uzn,emts par pilntiesīgu biedru Rakstnieku savienībā, ${ }^{96}$ bija izlēmis atraisīt savu balsi laikam tāpēc viņš arī bija aktīvs savienības politiskā semināra klausītājs, turklāt viṇam vienmēr bija raksturīga lojalitāte pret jebkuru režīmu: "[...] kaut arī kreisi noskan,ots, Čaks allaž bija lojāls pilsonis [...] Iespējams, Čaks gribēja palikt lojāls pilsonis arī padomju Latvijā". ${ }^{97}$ Pirmajā dzejolī (21. februārī) "Balāde par iesirmo kapteini" nodeva bija pavisam minimāla, kādi pāris vārdi:
Es stāvu vietā nelokāms, lai nost man abas rokas kalst, Ja to, ko uzliek Darba valsts, Mēs zemūdenē neveicam. ${ }^{98}$

Nākamajā dzejolī (pēc nedēḷas) nodeva jau bija lielāka: lai arī tas bija it kā veltīts slēpotāju krosam, tomēr ne gluži katram slēpotājam, bet slēpotājam - komjaunietim, kuram, tiesa, bija ne tikai jāslēpo:

\section{Sniegi laukus baltus klāj, \\ Skaidrais tālums pretim māj; \\ Komjauniet, slēpotāj, \\ Stāj! \\ Spēks, kas asā darba krāts, \\ Tãlā mērḳi triektais prāts, \\ Komjauniet, ciñai nāc, \\ Sāc. \\ Tālums spìd un garām slìd, \\ Vèji tev pie slēpēm krit; \\ Komjauniet, proti rit \\ Atvairit \\ Briesmas savai Dzimtenei, \\ Visai darba pasaulei; - \\ Komjauniet, droši skrej, \\ Hei! ${ }^{99}$}

Tas vēl nebūtu nekas briesmīgs, tāpat tāds nebija cits nieks 8. martā - "Sieviešu dienā" - "Dziesma par jauno pastnieci": 
Vēstule kā spalva.

Pašai smaida valgs.

Pasaule un dzive

Saujā lïkst kā zieds.

Ved zem rokas brive,

Kur bij skumji iets. ${ }^{100}$

Škiet, ka neviens A. Čaku nespieda iet tālāk, bet viṇš to darīja arvien spēcīgāk. Martā nāca dzejolis, veltīts Parīzes Komūnai (1871), "18. marts":

Grauj lielgabalu dārds, Un ložu krusas birst. Kam komūnāra vārds, Vai vinuu rindas irst?

Tie stāv un labāk mirst.

Viss gurdais elpā gaist, Kad atkal prātā nāk

Ikbrīdi varenāk,

Ar slavu apvitais

Marts astonpadsmitais. ${ }^{101}$

Tagad A. Čaks bija burtiski neapturams, un, protams, bija jānāk dziedājumam par L,eninu "Viņšs redzēja L,en,inu": par kādu Sarkanās armijas kareivi, kurš - tas ir zīmīgi - piedalās Sarkanās armijas uzbrukumā Polijai (1920):

“Pret paniem!" - balsìm pildās gaiss.

Pret paniem karogs sarkanais

Ved tālāk cīnā pulku.

Iet rindā jaunais kareivis,

Un drosme viña pierē viz

Ar nedzēšamu spulgu.

Vai šautene par smagu šksiet?

Vai tankam aukla val̦ā iet?

Nē! Viegla vina gaita.

Viņš iet, no vecā atbrīvots.

Jauns spēks un draugs ir vinam dots:

“Tas - L̦enins!” lūpas smaida. ${ }^{102}$

1. maijs bija svētku diena PSRS, un jau 1941. gada aprīlī dzejnieks to slavēja, salīdzinot ar 1940. gadu - kad viņš, kā atceramies, bija saṇēmis cienījamo A. Brigaderes prēmiju (galu galā - veseli 4000 latu), bet tagad to raksturoja kā posta laiku:

Gads gājis, nāvi projām gainot, Plìv brīvi karogs sarkanais Ar zvaigzni dzìvo, piecstaraino, Un viņam lìdzi pirmais maijs.

Mēs rindās ejam ielās koši, Nav liegta dziesma, krūtìm gaiss. Mēs darba svētkus svinam droši, Mums šodien visiem pirmais maijs.

Kas tevi saules klēpi lika, Kur gaisma mūžam nenoriet, Tu, piecpadsmitā republika, Lai celšs uz komunismu iet? Tas strādnieks, darba zemnieks blaku, Viens kopā lējies plecs un balsts;

Tie abi solo vienu taku,

Tiem abiem kopā viena valsts. ${ }^{103}$

Latviešu mākslas dekādei Maskavā bija jāuzraksta arī jauna opera, tas tika uzticēts Jāzepam Mediņam. Lai gan operai tā arī netika dots nosaukums, ${ }^{104}$ jau martā tika paziņots, ka libreta plānu esot izstrādājuši A. Čaks un Eriks Âdamsons: "Operas darbỉba norisinās Maskavā, uz Volgas, pie Valkas un Rìgā 1918. gadā, un galvenā loma tur ierādìta latviešu revolucionāriem strēlniekiem." ${ }^{105}$ Abi dzejnieki uzrakstīja operai 13 dziesmas, tai skaitā - pavisam neveiklu "Dziesmu par L,eninu”:

Un strēlnieki traucas, un zemnieki steidz Tiem lìdzi no druvām un siliem, Lidz armija izaug, un biedrs tad teic: - Miers būdiñām, karš lai ir pilìm! Un, lūk, ar šiem vārdiem, kas vareni plūst Pār sādžām un pilsētām senām, Uz laikmetu gaišu un taisnigu mūs Ved viņš - tautas draugs biedrs L̦eñins. ${ }^{106}$

Kulmināciju A. Čaka garīgais kolaboracionisms sasniedza jūnijā ar garu dzejoli 
“17. jūnijs”. Neviens ne līdz tam, ne vēlāk tik meistarīgi neapmīḷos okupācijas simbolu - Sarkanās armijas tanku -, kā to darīja A. Čaks:

\section{Lielcelı baltajos dvielıs \\ Tinušies tanki iet; \\ “Tumsu mums šurpu svied \\ Riteños dzēlos un lielos. \\ Tã mūsu nemieru mielos." \\ Motoru balsis dzied. - \\ Tēraudā sapñi zied. \\ Vabules kaltās un stiprās, \\ Bites, kas saldi dūc. \\ Pretim tām veras krūts. \\ Tālumi pārtrūkst kā dzīpars. \\ Zeme mums ripo kā stīpa. \\ Diezgan te kungiem būts. - \\ Pats savu vārpu plūc. ${ }^{107}$}

A. Sakse arī uzrakstīja dzejoli ar tādu pašu nosaukumu - "17. jūnijs", kuram bija tas pats varonis - PSRS tanks, taču tas nobālēja A. Čaka izdomas priekšā ("No brālu robežām, / no brīvās darba zemes / šurp tanki varenie / jau dārdēdami brauc", tā A. Sakse). ${ }^{108}$ Lai kā abi dzejnieki centās, viṇu darbi, tikko parādījušies, jau bija ideolog̣iski novecojuši ("Karoga" 6. numurs, kurā bija nodrukāts A. Čaka "17. jūnijs", laikam uz 17. jūniju - okupācijas gadadienu - vēl pat nebija iznācis). Tie pilnīgi atbilda stāstam, kas par 1940. gada jūniju tika stāstīts veselu gadu, - Sarkanā armija atbrīvojusi Latvijas darbaḷaudis no plutokrātu kundzības. Šajā stāstā tanks patiešām bija galvenais varonis. Taču pāris dienas pirms pirmās 1940. gada 17. jūnija gadadienas parādījās jauns stāsts, kuram būs lemts ilgs mūžs padomju Latvijas oficiālajā vēsturē, līdz pat 1988. gadam. 1941. gada 14. un 15. maijā, kad okupētā Latvija piedzīvoja brutālās masu deportācijas, notika padomju Latvijas rakstnieku pirmais kongress, kurā ar plašu runu uzstājās Arvīds Pelše. Par 1940. gada jūniju viņš neteica neko, toties par jūliju tika pateikts loti daudz: 1940. gada jūlija dienas "[...] ir latviešu tautas dzìvē vislielākais vēsturiskais notikums [...] Notika sociālistiskā revolūcija. Nodibinājās proletariāta diktatūra" ${ }^{109}$ Te ir izškiroša satura maiņa no atbrīvošanas, kuru veica ārējie spēki, līdz sociālistiskai revolūcijai, kuru veic paši Latvijas darbaḷaudis. Sākās "sociālistiskā revolūcija” - vēlāk uzvarēs apgalvojums, ka tā ir sākusies nevis jūlijā, bet tūlìt jūnijā, ${ }^{110}$ un Sarkanās armijas tanki vēl dažreiz tiks pieticīgi pieminēti, ${ }^{111}$ taču kopumā PSRS loma 1940. gada vasaras notikumos tiks, cik vien iespējams, mazināta un slēpta, bet "revolucionāru" darbība glorificēta. Šai versijai A. Čaka apmīlotie tanki nederēja, un nav brīnums, ka viṇa garais dzejojums netika cildināts padomju okupācijas gados.

A. Pelšes referāts ir zīmīgs vismaz vēl vienā ziṇā: jau 1941. gadā tajā bija pamanāms nākamais lielais okupētās Latvijas rusifikators. Viņa garā roka bija aizsniegusies līdz pat skolnieku sacerējumiem, kuri viņiem bija jāuzraksta, skolu beidzot, par tematu "Varen plaša mana zeme dzimtā". A. Pelše bija izskatījis vairākus desmitus darbu, un tie viņam nepatika: "[...] par nožēlošanu jāsaka, ka liela dalı jauniešu, šo tematu izstrādājot, nebija spējuši pacelties pāri Latvijas robežām. Lielākā daḷa Rigas meiteñu un zēnu savā fantāzijā nebija spējuši aizlidot tālāk par Gauju". ${ }^{112}$ Tas patiešām bija slikti - latviešu jaunieši rakstijja par Gauju, nevis par Volgu: nebija apjūsmojuši PSRS, "savu lielo, vareno, brinišk̦igo dzimteni". Viṇš to viniem noteikti pieminēs...

A. Pelšes runu klātienē A. Čaks nenoklausījās: grūti pateikt, kādu apstākḷu dēl viņš laikam kongresā nepiedalījās, ${ }^{113}$ taču izpildīt A. Pelšes uzdevumus vinš̌ jau bija pilnīgi gatavs. 


\section{ATSAUCES UN SKAIDROJUMI}

${ }^{1}$ J. V. Stalins literatūrā un mākslā. In: Jaunais Komunārs, 21.12.1940., 4. lpp.

2 "Kūlējini, kolhoznieki / Pilnas klētis piekūluši; / Vienu vārdu atceras: / Stalıin tēvam pateicas." Ķemeru apkārtnē, kā tika apgalvots, faktiski - izdomāts, esot parādījusies šāda "daina": "Liela zeme, plaši lauki, / Nevar vārdus saklausit, / Nevar tautas saskaitit: / Stalins visas apvienojis, / Miera zemē pārveidojis." Cit. no: ALMA ANCELĀNE. Stal̦ina tēls latviešu padomju folklorā. In: Literatūra un Māksla, 25.12.1949.; sīkāk sk.: ARTURS ŽviNKLIS, LEO JANSONS. Latviešu padomju folklora: klasisko folkloras formu vulgarizācijas mēǵinājums (1947-1954). In: LVIŽ 2016, Nr. 2, 136.-137. lpp.

${ }^{3}$ ALEKSANDRS ČAKs. Lielā Ferganas kanāla racēju vēstule Josifam Vissarionovičam Staḷinam. In: Karogs 1941, Nr. 1, 115. lpp.

${ }^{4}$ ARNOLDS KLOTIN̦š. Mūzika okupācijā. Latvijas mūzikas dzīve un jaunrade 1940-1945. Rīga 2011, 130. lpp.; Nesekmiggs dziesmu konkurss. In: Cīna, 01.05.1941., 12. lpp.

${ }^{5}$ ILGONIS BĒRsONS. Auseklītis zem āmura un kāškrusta. Rīga 2006, 164.-165. lpp.

${ }^{6}$ Koncerts konservatorijā. In: Darbs, 31.03.1941., 5. lpp.

${ }^{7}$ Dziesma par Stalinu. In: Karogs 1941, Nr. 4, 427. lpp.

${ }^{8}$ Dziesma par traktoru. In: Brīvais Zemnieks, 01.01.1941., 3. lpp.

${ }^{9}$ KLOTIŅŠ, Mūzika okupācijā, 129.-130. lpp.

${ }^{10}$ Nesekmīgs dziesmu konkurss.

${ }^{11}$ Kāda censone Skaidrīte Stunga sacerēja "Skrundas jauniešu dziesmu", kurā, protams, apmīloja Stalinu, bet diez vai to skandēja pat vienā pašā Skrundā. SKAIDRĪTE STUNGA. Skrundas jauniešu dziesma. In: Padomju Jaunatne, 16.10.1945., 3. lpp.

${ }^{12}$ ARNOLDS KLOTiN̦Š. Mūzika pēckara staḷinismā. Latvijas mūzikas dzive un jaunrade. 1944-1953. Rìga 2018, 237. lpp.

${ }^{13}$ Oktobra zvaigzne. In: JĀNIS SudrabKalns. Brāḷu saimē. Dzejas. Rīga 1947, 128. lpp.

${ }^{14}$ AlEKSANDRS ČAKs. Zem cēlās zvaigznes. Dzejoḷi un dzejojumi. Rìga 1948, 325. lpp.

${ }^{15}$ KLOTıN̦Š, Mūzika okupācijā, 130. lpp.

${ }^{16}$ Mūsu pirmajai mākslas dekadai tuvojoties. In: Darba Sieviete 1941, Nr. 10, 5. lpp.

${ }^{17}$ KLOTıN̦š, Mūzika okupācijā, 123. lpp.

${ }^{18}$ Drāmas teātrim Maskavā bija jārāda Rūdolfa Blaumaņa "Skoderdienas Silmačos", un tika paziņots, ka tikai politiski labi sagatavots kolektīvs spēs to paveikt: "Tādēl LPSR Drāmas teātra kolektivs tik cītigi studē VK(b)P vēstures iso kursu." Neskaitāmiem mēǵinājumiem un nepārtrauktiem meklējumiem pēc tā, kā lugu konceptuāli piemērot jaunajām prasībām klāt nāca t. s. politiskā izglìtība, kurai teātra kolektīvs tika pakḷauts četras dienas nedēḷā, agri no rìta, pirms mēgénājumiem. "Trešdiena ir seviş̌ki nopietna darba diena. Tad pirms mēgeinājumiem notiek semināri par partijas vēsturi. To vada teātra kolektīva locekli - dekorātors b. Lapiņš [Arturs Lapin̄š]." LPSR Drāmas teātra darba nedēla. In: Cīṇa, 19.03.1941., 6. lpp.

${ }^{19}$ Herberts LīKums. Kas gaidāms tēlotājās mākslās. In: Cīṇa, 07.12.1940., 1. lpp

${ }^{20}$ ILZE KonSTANTE. Staḷina garā ēna Latvijas tēlotājas mākslā. 1940-1956. Rīga 2017, 86. lpp.

${ }^{21}$ RŪDOLFS PINNIS. Glezniecība. Rīga 1990, 26. lpp.

${ }^{22}$ KĀRLIS BuŠs. Pirmā Latvijas PSR tēlotājas mākslas izstāde. In: Cīṇa, 08.01.1941., 3. lpp.

${ }^{23}$ Ibidem, 5. lpp.

${ }^{24}$ Ibidem.

${ }^{25}$ Ibidem.

${ }^{26}$ ANNA SAKSE. Periodikā izkaisītā literatūra. In: Cīn,a, 01.01.1941., 5. lpp.

${ }^{27}$ Ibidem. 
${ }^{28}$ KONSTANTE, Staliina garā ēna, 72. lpp.

${ }^{29}$ Suta prasa klasiski nevainojamu zīmējuma formu. TATJANA SUTA. Romans Suta. Rīga 1975, 81. lpp.

${ }^{30}$ Konstante, Stalina garā ēna, 88. lpp.

${ }^{31}$ JĀNIS DOMBrovskis. Portretists profesors Roberts Tilbergs. In: Atpūta, 28.06.1940.

${ }^{32}$ Sacensība hercoga Jēkaba piemiņai. In: Brīvā Zeme, 17.02.1940.

${ }^{33}$ MĀRIS BRANCIS. Jānis Roberts Tilbergs. Rīga 1996, 208. lpp.

${ }^{34}$ Latvijas PSR Mākslas Izstāde. In: Jaunais Komunārs, 05.01.1941.

${ }^{35}$ KonstanTE, Stalina garā ēna, 209. lpp.

${ }^{36}$ Uldis Zemzaris par Tilberga radīto Stalina portretu ir precīzi atzīmējis, ka Tilbergs "defilēja ar savu akadēmisko profesionalitāti”. UldIS ZEMZARIs. Mākslinieki dzīves ceḷā satikti. Vērojumi un atskārsmes. Rīga 2017, 65. lpp.

${ }^{37}$ INETA LIPŠA. Ulmaņa mīlestības pinekḷos. In: Rīgas Laiks 2012, Nr. 5, 36.-45. lpp., šeit 38. lpp.

${ }^{38}$ Ibidem, 41. lpp.

${ }^{39}$ KĀRLis Zemdega (sast.). Latviešu padomju tēlniecība (albums). Rīga 1960, 79. lpp.

${ }^{40}$ BRUNO TOMANIS. Revolūcijas dēli. Latviešu strēlnieki un sarkangvardi pirmajā padomju varas gadā. Rīga 1970, 16. lpp.

41 “L̦eñins pieceḷas un izstiepj roku / Pulkvedim - viņš uzvarai tic drošì. ALEKSANDRS ČAKs. Raksti. 3. sēj. Rīga 1973, 282. lpp.

42 "Kaujās ar Padomju valsts ienaidniekiem pilsoṇu kara gados redzama nozime piekrita latviešu strēlniekiem. Latviešu sarkanie strēlnieki varonigi cinijās pie Kazaņas, Orlas un Perekopa [...]" Uzticības zvērests sociālistiskai Dzimtenei. In: Padomju Latvija, 19.02.1941., 10. lpp.

${ }^{43}$ Biedrs Pēteris Plēsums. In: Cīṇa, 23.11.1940., 1. lpp.

${ }^{44}$ Pēteris Plēsums. PĒteris BAug̣is (red.). Mēs jaunu pasauli sev celsim. Sociālistiskā revolūcija Latvijā 1940. gadā. Atmiṇu krājums. 1. sēj. Rīga 1972, 348. lpp.

${ }^{45}$ Biedrs Roberts Neilands. In: Ciñu, 01.01.1941., 3. lpp.

${ }^{46}$ Josifs BARKovskis. Latgales komunisti cīṇā par revolūcijas uzvaru. In: BAUG̣IS, Mēs jaunu pasauli sev celsim, 250. lpp.

${ }^{47}$ Biedrs Varfolomejs Rubuls. In: Cīṇa, 07.01.1941., 4. lpp.

48 Pazinojums. In: Darbs, 23.05.1941., 5. lpp.

${ }^{49}$ Sk. sīkāk: KonSTANTE, Stalina garā ēna, 94.-95. lpp.

${ }^{50}$ Baltijas paviljona eksponāti Vissavienības lauksaimniecības izstādē. In: Cīṇa, 01.05.1941., 9. lpp.

${ }^{51}$ Baltijas republiku paviljons lauksaimniecības izstādē. In: Darbs, 13.05.1941., 1. lpp.

${ }^{52}$ R. KALNIN̦Š. Latvijas PSR Vissavienības lauksaimniecības izstādē Maskavā. In: Cīṇa, 25.05.1941., 5. lpp.

${ }^{53}$ VAidELOTIS Apsītis. Kārlis Zāle. Rīga 1988, 137. lpp.

${ }^{54}$ Par Zāli Petrogradā 1918. gadā sk. Ugas Skulmes atmiņas: UGA SKUlmE. Atmiņu grāmata. Rīga 2013, 158. lpp.

${ }^{55}$ Apsītis, Kārlis Zāle, 24.-25. lpp.

56 "Patlaban Meldera darbu stils kḷuvis konstruktīvi reāls un tajos spraigi izpaužas cilvēka k̦ermeña fiziskā un garīgā spēka dailums. "Es negribu galı tēlot, rēkinoties vienigi ar anatomiju, bet uzskatu cilvēka figūru arī kā celtni," - saka mākslinieks, šai celtnei, pēc tēlnieka domām, jābūt izteiksmïgai un konstruktīvai, ko tēlnieks sasniedz ar rūpigi pārdomātām figūru kustībām, lielā vienkārršībā pastrüpojot un izceḷot tikai raksturïgāko." JĀNIS DOMBROvsKIs. Dižais torņkalnietis - tēlnieks Emīls Melders. In: Atpūta, 02.06.1939., 24. lpp.

${ }^{57}$ SKAIDRĪTE CIELAVA (red.). Latviešu tēlotāja māksla. Rīga 1980, 8. lpp. 
${ }^{58}$ Attēlus sk.: ILGa STRAume (sast.). Emīla Meldera 80. dzimšanas dienai veltītās darbu izstādes katalogs. Rīga 1969.

${ }^{59}$ KonstAnTE, Staliina garā ēna, 98. lpp.

${ }^{60}$ Attēlu sk.: GaLINA KARKLIN'. Aleksandra Briedis. Moskva 1977, s. 102.

${ }^{61}$ KONSTANTE, Stalina garā ēna,118. lpp.

${ }^{62}$ KARKLIN', Aleksandra Briedis, s. 103.

${ }^{63}$ A. Briedes darbs uzskatāms par vienu no izcilākajiem padomju portreta mākslas ḷeniniānas sasniegumiem. Tas ir pārliecinošs heroiskā tēla paraugs. RUTA ČAUPOVA. Portrets latviešu tēlniecībā. Rīga 1981, 129. lpp.

${ }^{64}$ KonstAnTE, Staliina garā ēna, 85. lpp.

65 "Nopelnu pensijas komisija pie Latvijas PSR Tautas komisāru padomes pieškirusi personālpensiju uz visu mūžu dziedāšanas pedagogam Pāvulam Jurjānam, komponistam Alfrēdam Kalninam, Jāzepam Medinam, skulptoram Teodoram Zal̦kalnam un skatuves māksliniekiem Paulai Baltābolai, Bertai Rūmniecei, Aleksim Mierlaukam un Jūlijai Skaidrītei.” Piešķirtas pensijas. In: Brīvais Zemnieks, 05.05.1941.

${ }^{66}$ JĀNIS KALNAČs. Tēlotājas mākslas dzìve nacistiskās Vācijas okupētajā Latvijā. 1941-1945. Rīga 2005, 57. lpp.

${ }^{67}$ Pretim Saulei. In: Cīn,a, 26.03.1941., 5. lpp.

${ }^{68}$ Ibidem.

${ }^{69}$ Sīkāk sk.: KLOTIN̦Š, Mūzika okupācijā, 221.-222. lpp.

${ }^{70}$ VAlentīna Freimane. Padomju Latvijas kino pirmais gads. In: LiliJA Dzene, VikTors HAuSMANis, SilviJa Līce, MiKs Zvirbulis (red.). Padomju Latvijas kinomāksla. Mākslas, dokumentālās un multiplikācijas filmas. Rīga 1989, 18.-26. lpp., šeit 22. lpp.

${ }^{71}$ Pretim saulei. In: Jaunais komunārs, 04.04.1941.

${ }^{72}$ DZENE et al., Padomju Latvijas kinomāksla, 26. lpp.

${ }^{73}$ Nikolaja Virtas "Vientulība" VAPP republikas apgādā 1941. gadā. In: Jaunais Komunārs, 08.06.1941.

74 "Kad atausa rīts". Filmas scenārijs par Padomju Latvijas komūnistu cīṇu par padomju varu. In: Cīna, 25.05.1941., 6. lpp.

${ }^{75}$ Ibidem.

${ }^{76}$ Ibidem.

77 I. RIEKSTIN̦Š (red.). Kino. Kinoskatītāja Rokasgrāmata. Rīga 1980, 292. lpp.

${ }^{78}$ Cit. no: ILgA Gore, AIVARS Stranga. Latvija: neatkarības mijkrēslis. Okupācija. 1939. gada septembris - 1940. gada jūnijs. Rīga 1992, 162. lpp.

79 INGA PĒRKONE. Kino Latvijā 1920-1940. Rīga 2008, 246. lpp.

${ }^{80}$ ELMĀRS PELKAUS. Sociālistiskās kultūras izveide. Latvijas Komunistiskās partijas darbība kultūras revolūcijas īstenošanā. 1940-1959. Rìga 1983, 39. lpp.

${ }^{81}$ Freimane, Padomju Latvijas kino pirmais gads, 25. lpp.

${ }^{82}$ Gatavos skaņu filmu “Kaugurieši”. In: Latvijas Kareivis, 17.03.1940., 4. lpp.

${ }^{83}$ PĒRKone, Kino Latvijā, 220. lpp.

${ }^{84}$ Freimane, Padomju Latvijas kino pirmais gads, 23. lpp.

${ }^{85}$ Nobeigta filma "Kaugurieši". In: Cīña, 15.05.1941., 6. lpp.

${ }^{86}$ Freimane, Padomju Latvijas kino pirmais gads, 25. lpp.

${ }^{87}$ Filmu "Kaugurieši" redzēsim uz ekrāna. In: Padomju Students, 12.04.1946.

${ }^{88}$ LAIMA SlAVA (sast.). Romans Suta. Rīga 2016, 383. lpp. 
${ }^{89}$ ALEKSANDRs ČAKs. Raksti. 5. sēj. Rīga 1976, 310.-311. lpp.

${ }^{90}$ Čaks "[...] piedalījās dažās kaujās pret Antonova bandām. Vājas redzes dēl, vinš no aktīvās armijas atbrìvots [...]". ALEKSANDRS ČAKS. Raksti 1. sēj. Rīga 1971, 546. lpp. 1945. gada 6. februārī Čaks savā īsajā autobiogrāfijā rakstīja: "Antonova sacelšanās laikā ciniijos pret viña bandām Sarkanās Armijas ìpašo uzdevumu vienïbā [...]" AlEKSANDrs ČAKs. Kopoti raksti. 6. sēj. Proza, raksti, vēstules, autobiogrāfija. Rīga 2007, 955. lpp.

${ }^{91}$ SilviJa RADZOBE. "Kosmopolītu lieta” un Aleksandrs Čaks. Rīga 2017, 175. lpp.

${ }^{92}$ Ibidem, 176. lpp.

${ }^{93}$ Milda GRīnfelde, VALdis RŪMnieKs. Kāpēc es esmu Čaks? Rīga 1988, 22. lpp.

${ }^{94}$ VALDIS RŪMNIEKS, ANDREJS MiglA. Čaks. Biogrāfisks romāns. Rīga 2010, 516. lpp.

${ }^{95}$ BĒRSONS, Auseklītis zem āmura un kāškrusta, 76.-78. lpp.

${ }^{96}$ Ibidem, 126. lpp.

${ }^{97}$ Guntis BeRELIS. Latviešu literatūras vēsture. No pirmajiem rakstiem līdz 1999. gadam. Rīga 1999, 85. lpp.

${ }^{98}$ ALEKSANDRS ČAKs. Balāde par iesirmo kapteini. In: Atpūta, 21.02.1941., 9. lpp.

${ }^{99}$ AleKSANDRS ČAKs. Dziesma slēpotājiem. In: Atpūta, 28.02.1941., 22. lpp.

${ }^{100}$ AleKSANDRs ČAKs. Dziesma par jauno pastnieci. In: Padomju Latvija, 08.03.1941., 6. lpp.

${ }^{101}$ ALEKSANDRS ČAKs. 18. marts. In: Karogs 1941, Nr. 3, 302. lpp.

${ }^{102}$ ALEKSANDRS ČAKS. Vinš̌ redzēja L̦en,inu. In: Karogs 1941, Nr. 4, 450.-452. lpp., šeit 450. lpp.

${ }^{103}$ ALEKSANDRS ČAKs. Divi maiji. In: Karogs 1941, Nr. 4, 429.-431. lpp., šeit 430. lpp.

${ }^{104}$ KLOTıN̦Š, Mūzika okupācijā, 131. lpp.

${ }^{105}$ Top jaunā latviešu padomju opera. In: Padomju Latvija, 21.03.1941., 3. lpp.

${ }^{106}$ AlEKSANDRS ČAKS, ERIKS ĀDAMSONS. Dziesma par L̦eņinu. In: Cīna, 08.06.1941., 5. lpp.

107 ALEKSANDRS ČAKS. 17. jūnijs. In: Karogs 1941, Nr. 6, 745.-748. lpp., šeit 747. lpp.

${ }^{108}$ ANNA SAKSE. 17. jūnijs. In: Cīṇa, 17.06.1941., 3. lpp.

${ }^{109}$ Padomju Latvijas rakstnieku uzdevumi. LK(b)P CK sekretāra biedra A. Pelšes runa latviešu padomju rakstnieku kongresā. In: Cīn,a, 17.06.1940., 4.-5. lpp.

${ }^{110}$ Sk. sīkāk: ĒRIKS ŽAGARs. Sociālistiskie pārveidojumi Latvijā 1940-1941. Rīga 1975, 20.-21. lpp.

${ }^{111}$ Piemēram, pirmajā akadēmiskajā Latvijas vēsturē, kura iznāca okupētajā Latvijā 1959. gadā, bija pieminēts, ka 1940. gada 21. jūnijā, kad no Rīgas Centrālcietuma tika atbrīvoti tur ieslodzītie komunisti, "Padomju Armijas dą̧u pavēlnieciba novietoja tankus pie cietuma ēkas [...]". KĀRLIS STRAZDIN̦Š (red.). Latvijas PSR vēsture. III sēj. No 1917. gada līdz 1950. gadam. Rìga 1959, 376. lpp.

${ }^{112}$ Padomju Latvijas rakstnieku uzdevumi.

${ }^{113}$ BĒRsONS, Auseklītis zem āmura un kāškrusta, 179. lpp.

\section{SUMMARY}

The article consists of several essays devoted to Sovietisation of Latvian culture after the occupation and annexation of Latvia. The article is based on archival research, studies of the press and memories published in Soviet period and after the restoration of independence. Extensive studies of research literature dedicated to the problem also form the basis of the current article.

Already during the first days after occupation of Latvia, the Communist Party started to brutally assail Latvian culture and art, enforcing new tasks and topics thereupon. 
One of the high-ranking politicians who had an enormous role in the sovietisation of the Latvian culture was Arvìds Pelše, quite early starting to accentuate the necessity for Russification. The occupation authorities operated in several directions. One of the tasks for Latvian poets, just like in other Soviet republics, was to create poems about Stalin. However, first big poem devoted to Stalin appeared only in 1948. Some translations of poems about Stalin appeared in the Latvian press.

At the end of 1940, it was planned to organize a 'decade of Latvian art' in Moscow, scheduled for the spring of 1941. Soviet Latvian authorities were ready to please Moscow, however, the decade was postponed, and the beginning of Soviet - German war destroyed aforementioned plans. The preparatory works for the decade revealed serious problems. Latvian artists did not fully adapt to socialistic realism, for example, traditional Latvian painting was termed as formal and far from people. Pompous formalism in painting surprisingly corresponded to Soviet demands best of all. Nevertheless, the preparation for 'decade' demonstrated that many artists were ready for unpleasant servility.

The sculpture is the most politicized branch of fine arts: those who have power, have always wanted to perpetuate themselves in bronze and marble; sculptors have always tried to obtain profitable orders from governments. The first statues of Lenin and Stalin were ordered, but there was no prominent success. The statue of Rainis was also discussed, poet Rainis was made a symbol of the new era. The idea to immortalise Latvian Red Riflemen opened the issue about their role in Bolshevik revolution and its interpretations during Stalin's repressions. Most of the riflemen were executed, and their names were erased from official history.

Several movies were also planned. Their objective was, for example, to criticise the bourgeois period in the Republic of Latvia and reflect the achievements after 1940. The only movie that was actually elaborated was a documentary film "Towards the Sun", it was recognised as weak and unconvincing.

Famous poet Aleksandrs Čaks possessed a special place in the poetry of the Soviet period, publishing poems in literary magazines and daily newspapers. They were devoted to Lenin and the life of people; the glorification of the Soviet occupation and tanks was especially miserable. Fear from the Soviet regime explains his servility, since his previous poems were considered as patriotic and even nationalist. 